\title{
Two-Component Two-Phase Critical Flow
}

Milan M. Petrovic

Research Assistant University of Belgrade Faculty of Mechanical Engineering

Vladimir D. Stevanovic Full Professor University of Belgrade Faculty of Mechanical Engineering
A model of two-component two-phase critical flow is presented. The modelling approach is based on one-dimensional homogeneous gas-liquid two-phase isentropic flow of mixture. The homogeneous model is modified by taking into account the void fraction and two-phase mixture density dependence on velocity slip. The velocity slip is calculated using Chisholm correlation that depends on the gas phase quality and Zivi correlation for the prediction of the maximum velocity slip values. At the location of the critical flow the two-phase mixture velocity equals sonic velocity and it is calculated with the so-called "'frozen sonic velocity" model. The model is validated against data measured in air water flow at the PUMA experimental facility. Obtained results are presented together with the predictions by the well-known Fauske model. It is shown that Fauske model overpredicts measured critical mass fluxes, while the present model shows acceptable agreement with the measured data.

Keywords: critical flow, two-phase flow, homogeneous model, air-water flow.

\section{INTRODUCTION}

Critical two-phase flow can occur when liquid and gas phase mixture leaks from a pipe or a vessel at a higher pressure to a pipe, a vessel or an atmosphere at a lower pressure through an opening. The flow through the opening is choked, which means that the flow rate does not depend on the down-stream pressure value. The critical flow occurs in safety valves, during blowdown transients of pressurized systems or conditions of sudden raptures of pipelines fittings, or vessels.

The critical velocity at the location of two-phase choked flow depends on the quality of two-phase mixture, the two-phase flow pattern, the slip between liquid and gas phase velocities and the liquid phase flashing. The non-linear dependence of critical velocity on the mentioned choked flow conditions might lead to a critical velocity value that is lower than the sonic velocity in the gas phase.

Early theories of critical flow have been proposed by Fauske [1], Levy [2], Moody [3], Henry [4] and Wallis [5]. The concept of two-phase is more complicated than critical single phase flow due to thermal and velocity non-equilibrium effects between liquid and gas phase. In general, the choking flow models can be classified as homogeneous equilibrium, homogeneous nonequilibrium, non-homogeneous equilibrium, and nonhomogeneous non-equilibrium models [6]. The early choking flow models are based on isentropic expansion and thermodynamic equilibrium. Homogeneous equilibrium model is based on the assumptions of no slip between phases and thermal equilibrium between phases.

Received: March 2015, Accepted: November 2015

Correspondence to: Vladimir D. Stevanovic

Faculty of Mechanical Engineering,

Kraljice Marije 16, 11120 Belgrade 35, Serbia

E-mail: vstevanovic@mas.bg.ac.rs

doi: $10.5937 /$ fmet1602109P

() Faculty of Mechanical Engineering, Belgrade. All rights reserved
These assumptions mean that there is no difference between liquid and gas velocity and the pressure and the temperature of liquid and gas phase are equal. Wallis [7] gave a detailed overview of critical flow theories and analytical approaches that deal with two-phase critical flow. Lemonnier and Selmer-Olsen [8] performed experimental and theoretical research of two-phase twocomponent flow in a converging-diverging nozzle. They also present developed model for dispersed flow using thermal equilibrium assumption.

The critical discharge rate at two-phase flow is also affected by the geometry of nozzle. The length to diameter ratio, the entrance effect and the shape of the nozzle are key elements to this investigation. Kim [9] gives a detailed overview of geometrical effects on the critical flow rate of subcooled and saturated water. He suggested a correlation which can be applicable for a wide range of stagnation pressures. The length and the diameter aspects were especially investigated.

In this paper a model of two-component two-phase critical flow is developed. Compressibility of the flow is taken into account. The modified homogeneous model of two-phase flow is applied. It is assumed that the liquid and gas phase are in thermal equilibrium, but the slip between gas and liquid phase velocities is taken into account in the calculation of the gas phase volume fraction and the density of two-phase mixture. In order to determine the existence of critical or subcritical flow conditions, both critical and subcritical velocities are calculated and the type of flow is determined by adopting a lower value of these two velocities. The subcritical two-phase flow is calculated by the model of two-phase flow through an orifice, as presented by Chisholm [10]. The developed model of two-phase critical flow is validated against data measured in the air water flow, at the PUMA experimental facility [11]. A good agreement of the present model data with measured values is achieved by appropriate modelling 
of the slip between liquid and gas phase velocities. In addition, results obtained with the Fauske model [1] are presented for the same critical flow conditions. The results of the present developed model show better agreement with measured data than the results obtained with the Fauske model [1].

\section{MODELLING APPROACH}

\subsection{Mathematical model of critical two-phase flow}

Isentropic flow is assumed from the upstream location very close to the opening and the opening where choked flow takes place, as presented in Figure 1.

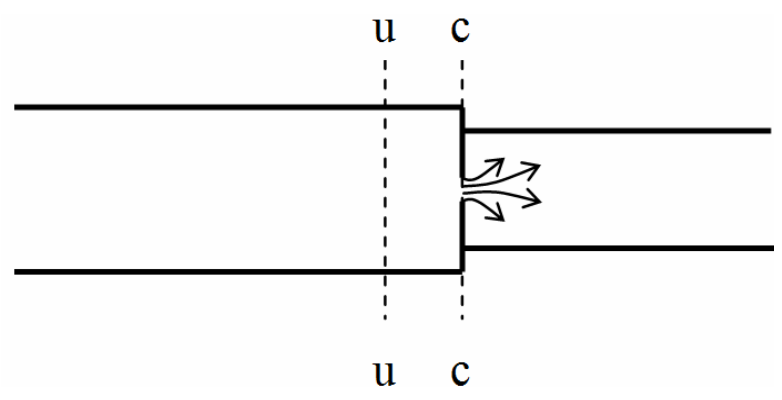

Figure 1. Locations of the choked flow (c) and infinitesimal upstream flow cross section (u)

The following form of mass and energy conservation equations is used to describe one-dimensional isentropic flow of a homogenous fluid. The mass balance for the flow from the upstream cross section $u$ to the location of choked flow $c$ is written as

$$
u_{u} A_{u} \rho_{u}=u_{c} A_{c} \rho_{c}
$$

where $u$ is velocity, $A$ is the area of flow cross-section and $\rho$ is density. The following energy equation holds for isentropic flow between cross sections $u$ and $c$

$$
h_{u}+\frac{u_{u}^{2}}{2}=h_{c}+\frac{u_{c}^{2}}{2}
$$

where $h$ is enthalpy of two-phase flow mixture. The following relations hold for the isentropic flow

$$
\int_{u}^{c} d h=\int_{u}^{c} \frac{d p}{\rho}
$$

and

$$
\frac{p_{u}}{\rho_{u}^{\kappa}}=\frac{p_{c}}{\rho_{c}^{\kappa}}=\frac{p}{\rho^{\kappa}}
$$

Integration in equation (3) by using relation (4) leads to the following relation for enthalpy change:

$$
h_{c}-h_{u}=\frac{\kappa}{\kappa-1} \frac{p_{u}}{\rho_{u}}\left[\left(\frac{\rho_{c}}{\rho_{u}}\right)^{\kappa-1}-1\right]
$$

At the location of choked and isentropic flow the two-phase mixture velocity equals sonic velocity $c_{c}$

$$
u_{c}=c_{c}=\left(\frac{\partial p}{\partial \rho}\right)_{s, c}^{1 / 2}=\sqrt{\kappa p_{c} / \rho_{c}}
$$

By combining equations (2) and (5) and using equations (1), (4) and (6) the following relation is obtained for the ratio of two-phase mixture densities in cross sections $u$ and $c$

$$
\frac{\rho_{c}}{\rho_{u}}=\left(\frac{1+\frac{\kappa-1}{2}\left(\frac{A_{c}}{A_{u}}\right)^{2}\left(\frac{\rho_{c}}{\rho_{u}}\right)^{\kappa+1}}{\frac{\kappa+1}{2}}\right)^{\frac{1}{\kappa-1}}
$$

The density ratio $\rho_{c} / \rho_{u}$ is calculated iteratively from equation (7) for prescribed upstream values of $p_{u}$ and $u_{u}$. The critical pressure $p_{c}$ is calculated with equation (4) and the critical velocity is calculated with equation (1). It should be mentioned that the isentropic expansion coefficient $\kappa$ changes for a flow between cross sections $u$ and $c$.

Therefore, the mean value of the isentropic expansion coefficient $\kappa$ between cross sections $u$ and $c$ is adopted. The isentropic expansion coefficient $\kappa$ in the equation (7) is calculated from equations (6) as

$$
\kappa=\frac{c^{2}}{p / \rho}
$$

The sonic velocity $c$ in equation (8) is calculated with the so-called "frozen two-phase sonic velocity" model [12] as

$$
c=\left[\frac{\partial \rho}{\partial p}\right]^{-\frac{1}{2}}
$$

where $\rho$ is the two phase mixture density calculated as

$$
\rho=\alpha \rho_{2}+(1-\alpha) \rho_{1}
$$

and $\alpha$ represents volume fraction of gas in two phase mixture and it is given by

$$
\alpha=\frac{1}{1+\frac{1-\chi}{\chi} S \frac{\rho_{2}}{\rho_{1}}}
$$

In equations (10) and (11) indices 1 and 2 denote liquid and gas phase respectively. The velocity slip is $S=u_{2} / u_{1}$. The flow quality is calculated as the ratio of gas phase mass low rate to total mass flow rate of twophase mixture as follows

$$
\chi=\frac{\dot{m}_{2}}{\dot{m}_{1}+\dot{m}_{2}}
$$

Equation (9) is differentiated under assumption that no phase change occurs and neglecting the velocity slip dependence on pressure. The following expression for the void fraction change with the pressure is obtained

$$
\frac{\partial \alpha}{\partial p}=\frac{\alpha(1-\alpha)}{\rho_{1}} \frac{\partial \rho_{1}}{\partial p}-\frac{\alpha(1-\alpha)}{\rho_{2}} \frac{\partial \rho_{2}}{\partial p}
$$


After combining equations (9), (10), (11) and (12), the sonic velocity from equation $(8)$ is calculated as

$$
\begin{aligned}
& c=\left[\left(\alpha^{2}+\alpha(1-\alpha) \frac{\rho_{1}}{\rho_{2}}\right) \frac{\partial \rho_{2}}{\partial p}+\right. \\
& \left.\left((1-\alpha)^{2}+\alpha(1-\alpha) \frac{\rho_{2}}{\rho_{2}}\right) \frac{\partial \rho_{1}}{\partial p}\right]^{-\frac{1}{2}}
\end{aligned}
$$

Finally, expression for the sonic velocity is calculated as

$$
c=\left[\frac{\alpha \rho}{\rho_{2} c_{2}^{2}}+\frac{(1-\alpha) \rho}{\rho_{1} c_{1}^{2}}\right]^{-1 / 2}
$$

The slip velocity in equation (11) is calculated with the following parametric function which combines Chisholm correlation for the lower quality values [13] and Zivi correlation as the maximum value of gas and liquid phase velocity slip [13]

$$
S=\left\{\begin{array}{l}
S_{\text {Chislom }}, S_{\text {Chislom }}<S_{\text {Zivi }} \\
S_{\text {Zivi }}, S_{\text {Chislom }}>S_{\text {Zivi }}
\end{array}\right.
$$

where

$$
S_{\text {Chisholm }}=\left[1+\chi\left(\frac{\rho_{1}}{\rho_{2}}-1\right)\right]^{0.5}
$$

and

$$
S_{\text {Zivi }}=\left(\frac{\rho_{1}}{\rho_{2}}\right)^{1 / 3}
$$

\subsection{Subcritical two-phase flow through orifices}

Depending on the difference between the opening upstream and downstream pressure, the two-phase flow through the opening can be subcritical or critical. In case of subcritical flow the flow rate through the opening depends on its dimensions, the upstream and downstream pressure ratio and upstream two-phase flow parameters, such as liquid and gas phase densities and two-phase mixture quality. In case of choked flow the flow rate also depends on the opening dimensions and upstream two-phase mixture parameters, but it does not depend on the downstream pressure, i.e. for the constant upstream parameters the flow rate is constant, regardless of the value of the downstream pressure.

The existence of the critical or the subcritical flow condition is determined by comparison of velocities calculated by the critical two-phase flow model and the subcritical flow model. If the velocity calculated with the critical flow model is lower then the velocity calculated with the subcritical flow model, than the critical (choked) flow takes place at the opening. The subcritical two-phase flow model developed for flows through orifices is applied in this paper, since the orifice is the opening where the choked flow takes place in the experimental conditions that are simulated in the next section. The model presented by Chisholm in [10] is applied as follows.
Pressure drop in two-phase flow through the orifice is calculated as

$$
\Delta p=\Delta p_{1} \phi_{1}^{2}=\varsigma \frac{\rho_{1} u_{1}^{2}}{2} \phi_{1}^{2}
$$

where $\phi_{1}^{2}$ is two-phase multiplier and $u_{1}$ is liquid velocity upstream of the orifice in the case when liquid phase flows alone through the flow channel

$$
\dot{m}_{1}=\rho_{1} u_{1} A
$$

where $A$ is the area of total cross section of the flow channel. Two-phase mass flow rate through the orifice is calculated as

$$
\dot{m}=\frac{\dot{m}_{1}}{(1-\chi)}
$$

From equations (19-21) it follows:

$$
\dot{m}=\frac{A}{1-\chi}\left(\frac{2 \Delta p \rho_{1}}{\varsigma \phi_{1}^{2}}\right)^{\frac{1}{2}}
$$

Two-phase multiplier is defined as

$$
\phi_{1}^{2}=1+C Y+Y^{2}
$$

where $Y$ corresponds to the reciprocal of the LochartMartinelli parameter and according to [10] it is calculated as

$$
Y=\frac{C_{1}}{C_{2}} \frac{\chi}{1-\chi}\left(\frac{\rho_{1}}{\rho_{2}}\right)^{0.5} F
$$

The ratio of the liquid and gas phase concentration coefficients is calculated as

$$
\frac{C_{1}}{C_{2}}=0.666 \cdot 0.666^{-r}
$$

where $r$ is ratio of orifice downstream and upstream pressure $(r<1)$. The correlation equation (25) is obtained by the exponential regression of data from Table 13.1 in [10]. Constant $C$ in equation (23) is calculated as

$$
C=Z+\frac{1}{Z^{2}}
$$

where

$$
Z=\frac{1}{S}\left(\frac{\rho_{1}}{\rho_{2}}\right)^{1 / 2} \frac{1}{F^{1 / \kappa}},
$$

and constant $F$ in equation (24) is calculated by expression

$$
F=\left(\frac{1-r}{r^{2 / \kappa}} \frac{1}{1-r^{(\kappa-1) / \kappa}} \frac{\kappa-1}{\kappa}\right)^{1 / 2}
$$

Velocity slip S in equation (27) is calculated with equations (16-18). The local flow resistance coefficient $\zeta$ in equations (19) and (22) is calculated for the single 
phase flow through orifice according to experimental correlation from [14]

$$
\varsigma=a\left(\frac{A_{o}}{A_{u}}\right)^{2} \exp (b)
$$

where

$$
a=18.78-7.78 \frac{A_{o}}{A_{u}}+6.337\left(\frac{A_{o}}{A_{u}}\right)^{2}
$$

and

$$
b=\left[-0.942-7.246 \frac{A_{o}}{A_{u}}-3.878\left(\frac{A_{o}}{A_{u}}\right)^{2}\right] \log (\mathrm{Re})
$$

where $A_{o}$ represents the area of flow cross section at the orifice and $A_{u}$ is the upstream cross section area. The Reynolds number is calculated for the orifice velocity and hydraulic diameter

$$
\operatorname{Re}=\frac{u_{o} D_{h, o}}{v_{o}}
$$

The orifice hydraulic diameter is calculated as $D_{h, o}=\frac{4 A_{o}}{P_{o}}$, where $P_{o}$ is orifice flow cross section parameter and $v_{o}$ kinematic viscosity.

\section{RESULTS}

The developed choked flow model is validated against measured data of air and water two-phase flow through the orifice. The choking flow experiments were performed using PUMA (Purdue University Multidimensional integral test Assembly) experimental facility [11]. The inner diameter of the simulated test section tube was $24.4 \mathrm{~mm}$, while the orifice diameter was $5.4 \mathrm{~mm}$. Obtained results are presented in Figures 2-6 together with the predictions obtained with the Fauske model. The experimental upstream pressure conditions were $0.207 \mathrm{MPa}, 0.345 \mathrm{MPa}, 0.689 \mathrm{MPa}$ and $1.034 \mathrm{MPa}$, respectively.

Critical flow model and prediction for the critical mass flux based on the non-homogeneous equilibrium assumption proposed by Fauske [1] are given as follows

$$
G=\left[-\frac{S}{d \frac{\partial v_{2}}{\partial p}+\left(v_{2} e+v_{1} f\right) \frac{\partial \chi}{\partial p}+g \frac{\partial v_{1}}{\partial p}}\right]^{\frac{1}{2}}
$$

where

$$
\begin{gathered}
d=\{(1-\chi)+S \chi\} \chi \\
e=1+2 \chi(S-1) \\
f=2 \chi S(1-S)-2 S\left(1-\frac{1}{S}\right) \\
g=\left\{S\left[1+\chi(S-2)-\chi^{2}(S-1)\right]\right\}
\end{gathered}
$$

The velocity slip $S$ in the Fauske model is determined by the maximum of the two-phase flow kinetic energy

$$
S=\left(\frac{\rho_{1}}{\rho_{2}}\right)^{\frac{1}{2}}
$$

It is shown that the Fauske model [1] overpredicts measured critical mass fluxes, while the present model shows acceptable agreement with the measured data. The weak point of the Fauske model is considered constant slip ratio based on density, which is not applicable for the low quality region. The discrepancy is higher as the flow quality decreases. The model developed in this paper takes into account the slip dependence on the flow quality (equation 16) which leads to much better prediction of choked flow rate. All results presented in Figures 2-6 correspond to choked flow.

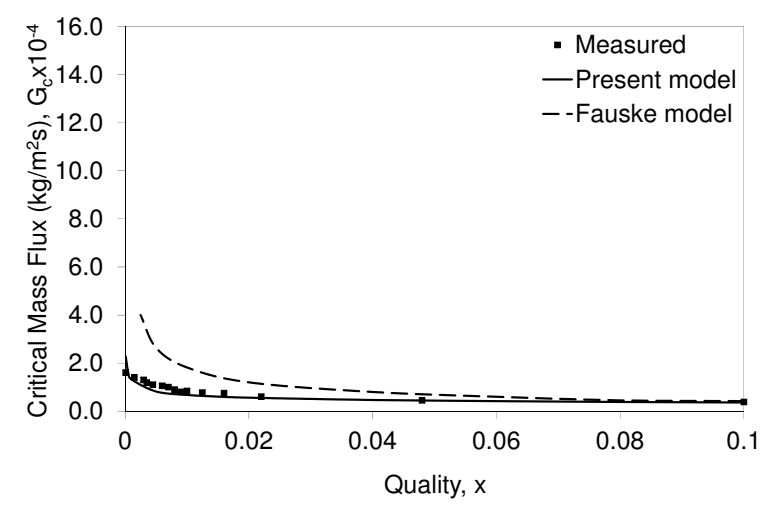

Figure 2. Comparison of measured and calculated choking mass fluxes, experimental upstream pressure is $0.207 \mathrm{MPa}$

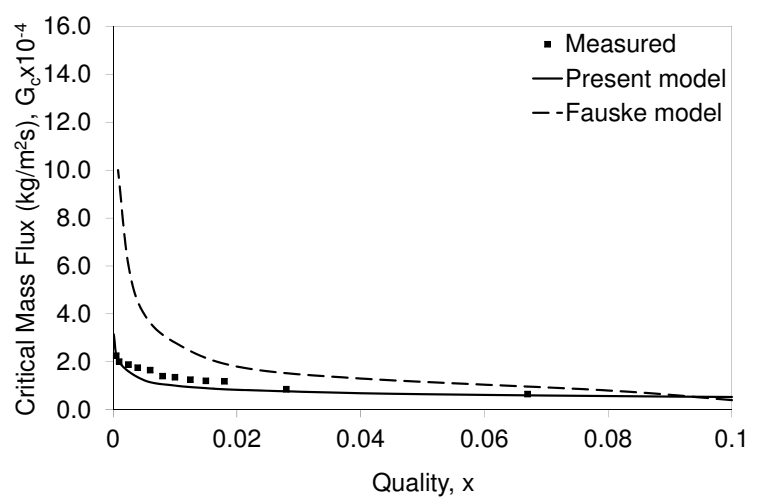

Figure 3. Comparison of measured and calculated choking mass fluxes, experimental upstream pressure is $0.345 \mathrm{MPa}$

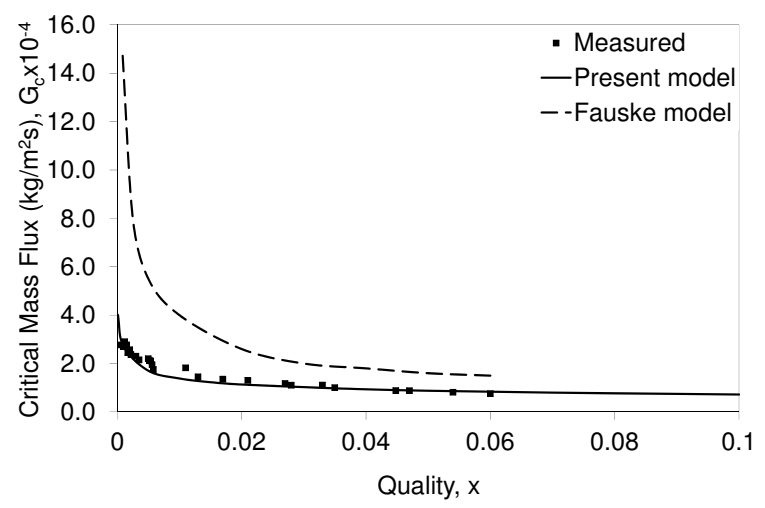

Figure 4. Comparison of measured and calculated choking mass fluxes, experimental upstream pressure of $0.517 \mathrm{MPa}$ 


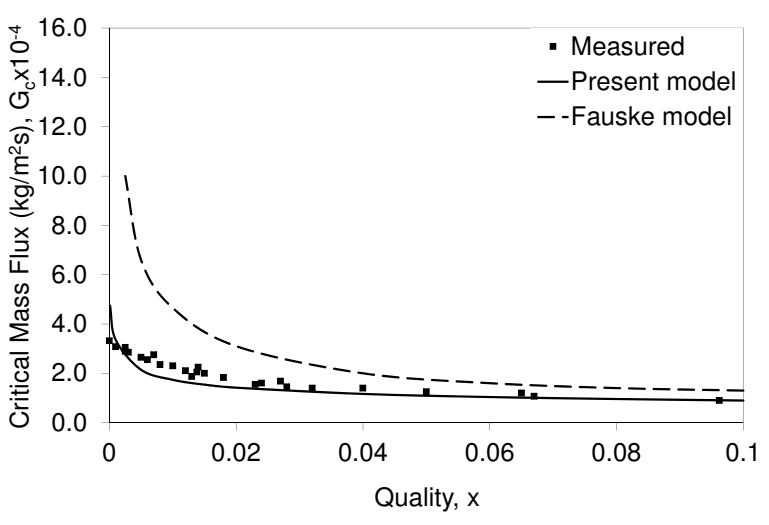

Figure 5. Comparison of measured and calculated choking mass fluxes, experimental upstream pressure is $0.689 \mathrm{MPa}$

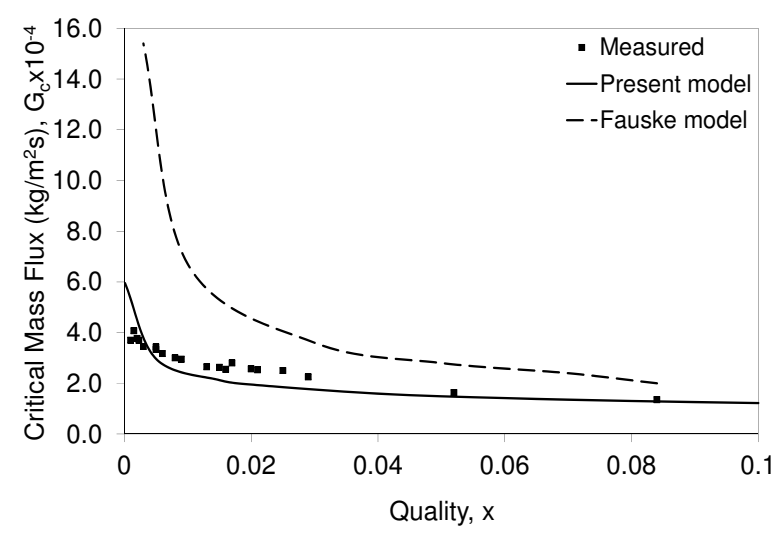

Figure 6. Comparison of measured and calculated choking mass fluxes, experimental upstream pressure is $1.034 \mathrm{MPa}$

\section{CONCLUSION}

In order to calculate the critical two-phase flow rate, the analytical model is developed. It is validated against measured data of air and water two-phase flow. Obtained results are presented together with the predictions of the well-known Fauske model. It is shown that Fauske model overpredicts measured critical mass fluxes, while the present model shows acceptable agreement with the measured data. The better agreement of the present model data is achieved by appropriate modelling of the slip between liquid and gas phase velocities. Namely, the velocity slip dependence on the quality is taken into account. In order to determine the existence of the critical or the subcritical flow condition, the presented model firstly calculates critical and subcritical velocities and by comparing them determines what kind of flow takes place at the opening.

\section{ACKNOWLEDGMENT}

This work was supported by the Ministry of Education and Science of the Republic of Serbia (Grant No. 174014).

\section{REFERENCES}

[1] Fauske, H.K.: Contribution to the Theory of TwoPhase, One-Component Critical flow, ANL-6633, Argonne National Laboratory, 1962.

[2] Levy, S.: Prediction of Two-Phase Critical Flow rate, ASME 64-HT-8, 1964.
[3] Moody, F.J.: Maximum Flow Rate of a Single Component, Two-Phase mixtures, Journal of Heat Transfer, pp. 134-142, 1965.

[4] Henry, R.E.: A Study of One- and TwoComponent, Two-Phase Critical Flows at Low Qualities, ANL-7430, Argonne National Laboratory, 1968.

[5] Wallis, G. B.: One-Dimensional Two-Phase Flow, Chapter 2 and Chapter 3, pp. 207-222, McGrawHill, New York, 1969.

[6] Yoon, H.J., Ishii, M., Revankar, S.T.: Choking flow modelling with mechanical non-equilibrium for two-phase two-component flow, Nuclear Engineering and Design, Vol. 236, pp. 1886-1901, 2006.

[7] Wallis, G.B.: Critical Two-Phase Flow, Multiphase Flow, Vol. 6, pp. 97-112, 1980.

[8] Lemonnier, H., Selmer-Olsen, S.: Experimental investigation and physical modelling of two-phase two component flow in a converging-diverging nozzle, Multiphase Flow, Vol. 18, No. 1, pp. 1-20, 1992.

[9] Kim, Y.S.: Overview of geometrical effects on the critical flow rate of sub-cooled and saturated water, Anals of Nuclear energy, Vol. 76, pp 12-18, 2015.

[10] Chisholm, D.: Two-phase Flow in Pipelines and Heat Exchangers, George Godwin, London, 1983.

[11] Ishii, M., Revankar, S.T., Leonardi, T., Dowlati, R., Bertodano, M.L., Babelli, I., Wang, W., Pokharna, H., Ransom, V.H., Viskanta, R., Han, J.T.: Scientific Design of Purdue University MultiDimensional Integral Test Assembly (PUMA) for GE SBWR, Purdue University Report PU-NE-94/1, U.S. Nuclear Regulatory Commision report NUREG/CR-6309, 1996.

[12] Grolmes, M.A., Fauske, H.K.: Comparison of the Propagation Characteristics of Compression and Rarefaction Pressure Pulses in Two-Phase, OneComponent Bubble Flow, Transactions of the American Nuclear Society, Vol. 11, pp. 6833, 1968.

[13] Whalley, P.B.: Two-Phase Flow and Heat Transfer, Oxford University Press, Oxford, 1996.

[14] Idelchik, I.E.: Handbook of Hydraulic Resistance, Mashinostroenie, Moskva, 1992.

\section{NOMENCLATURE}

$\begin{array}{ll}a & \text { parameter in equation (29), } \\ A & \text { cross section area, } \mathrm{m}^{2}, \\ b & \text { parameter in equation (29), } \\ c & \text { sonic velocity, } \mathrm{m} / \mathrm{s}, \\ c_{p} & \text { specific heat, } \mathrm{J} / \mathrm{kgK}, \\ d & \text { parameter in equation (33), } \\ D_{\mathrm{h}} & \text { hydraulic diameter, } \mathrm{m}, \\ e & \text { parameter in equation (33), } \\ h & \text { specific enthalpy, } \mathrm{J} / \mathrm{kg}, \\ f & \text { parameter in equation (33), } \\ G & \text { mass flux, } \mathrm{kg} / \mathrm{m}^{2} \mathrm{~s} \\ F_{r} & \text { Froude number, } \\ \dot{m} & \text { mass flow rate, } \mathrm{kg} / \mathrm{s}\end{array}$




$\begin{array}{ll}p & \text { pressure, } \mathrm{Pa} \\ \mathrm{Re} & \text { Reynlods number, } \\ S & \text { velocity slip, } \\ u & \text { velocity, } \mathrm{m} / \mathrm{s}\end{array}$

\section{Greek symbols}

$\alpha \quad$ volume fraction,

$\kappa \quad$ isentropic expansion coefficient

$\phi \quad$ two-phase multiplier

$\rho \quad$ density, $\mathrm{kg} / \mathrm{m}^{3}$

$\varsigma \quad$ local flow resistance coefficient,

$\chi \quad$ flow quality

\section{Index}

$1 \quad$ liquid phase

o orifice

$\mathrm{u} \quad$ upstream cross section

c critical cross section

\section{КРИТИЧНО ДВОФАЗНО СТРУЈАҢЕ} ДВОКОМПОНЕНТНЕ МЕШАВИНЕ

Милан М. Петровић, Владимир Д. Стевановић,
У раду је представљен модел двокомпонентног двофазног критичног струјања двофазне мешавине. Модел је валидиран поређењем рачунских резултата са вредностима измереним на PUMA експерименталној инсталацији. Модел је заснован на једнодимензионалном модификованом хомогеном изентропском двофазном струјању течности и гаса. Хомогени модел је модификован тако што је клизање између фаза узето у обзир при одређивању запреминског удела гасне фазе у двофазној мешавини, што одређује и густину двофазне мешавине. Клизање између фаза је срачунато на основу Chisholm корелације која је погодна за ниже вредности масеног проточног удела гасне фазе као и на основу Zivi корелације која одређује максималну вредност клизања између фаза. На месту критичног истицања брзина двофазне мешавине је једнака брзини звука и срачуната је на основу такозваног замрзнутог модела двофазног струјања који не узима у обзир фазни прелаз. Остварени резултати су приказани и упоређени заједно са добро познатим Fauske моделом доступним у литератури. Показано је да Fauske модел даје више вредности критичног масеног флукса у односу на измерене вредности, док модел приказан у раду даје прихватљива слагања са измереним подацима. 